\title{
Professor Władysław Pawlak 26 July 1931 - 3 August 2016
}

Professor Władysław Pawlak, the prominent figure of Polish geography and cartography, passed away in Wrocław on 3 August 2016. For many years he headed the Department of Cartography of Wrocław University; he was an outstanding representative of the Wrocław school of cartography and a mentor of many generations of Polish cartographers.

Władysław Pawlak was born on the 26 July 1931 to a peasant family in a village of Dobra near Limanowa in southern Poland. There he spent his childhood and attended elementary school (1939-1945). Two other well known Polish cartographers also came from that region. Józef Wąsowicz (1900-1964), the closest associate of Eugeniusz Romer and the founder of the Chair of Cartography at Wrocław University (1953) was born and grew up in Limanowa. Władysław Migacz (1912-1980), a collaborator and successor of J. Wasowicz at the Chair of Cartography of Wrockaw University was also born not far away, in Nowy Sącz. Also E. Romer had links to the city of Nowy Sącz - for five years, until his maturity exam in 1889 , he had attended the Imperial-royal Gymnasium (secondary school) there. In the following years the three professors from the Nowy Sącz region: J. Wąsowicz, W. Migacz and W. Pawlak would be acknowledged as the founders of the Wroclaw school of cartography, the subsequent generations of which continue and creatively develop ideas of the school, initiated by E. Romer in Lwów in the period between the World Wars.

In the years 1947-1949 the young Władysław Pawlak attended courses of agricultural training. Soon, however the ambitious youth was accepted at the Preparatory Study in Cracow, and after graduation from it he started to study geography at the Jagiellonian University. After the second year he transferred to the Department of Natural Sciences of Wrocław University where he continued his studies at the newly founded cartography specialization. In 1955 he graduated with a Master's thesis titled Western Hemisphere - physical map in 1:40 000 000, supervised by Professor J. Wąsowicz. He linked



his whole life to Lower Silesia and Wrocław. In 1968 he married Janina Adamaszek, with whom he had two children, Katarzyna (born 1969) and Marcin (born 1972),

$\mathrm{He}$ started his professional career in the Wrocław Production Division of the State Cartographical Publishing House (PPWK), where he got promoted from the position of geographer - cartographer to the position of senior editor. He supervised the edition of, among others, the wall physical map of North America (Warsaw 1957, 1st edition; 1966, 4th edition). Together with Jan Knopik he edited the Geographical Atlas for grades V-VIII (Warsaw 1964, 1st edition; 1975 12th edition) which was later 
republished many times. During his studies and in his professional endeavors Władysław Pawlak collaborated with Prof. J. Wąsowicz and Prof. W. Migacz. These contacts resulted in gaining practical editorial experience and shaped his views on cartography and on school cartography in particular.

In 1964 he started working at Wrocław University. His scientific interests focused on theoretical and practical aspects of cartographic editing and particularly on generalization. Cartographic methodology and applied cartography, in which he creatively developed the ideas of the Wrocław school of cartography, were also important areas of his activity. In 1968 he got a Ph.D. degree from his Alma Mater for the thesis titled Character of distortion of selected elements of map contents resulting from the process of cartographic generalization (Wroclaw 1971). He continued this topic in his following book Some problems of generalization of hypsometry (Wrocław 1972) and in numerous articles, the most important of which include: Pre-graphic stage of cartographic generalization, published in Polish ("Polish Cartographical Review" 1988), Tchech (Brno 1988) and German (Dresden 1988), Computer generalization of rivers in the light of a single experiment ("Polish Cartographical Review" 1993) and From simplification to cartographic synthesis ("Main Problems of Contemporary Cartography" 2001).

Władysław Pawlak conducted further research on methods of presentation of terrain relief and problems of its cartographic generalization referring to shading, the most difficult method of relief presentation. In 1978 he presented his habilitation thesis Theoretical and technical problems of shading on maps. In 1986 he became a Professor.

In 1973-1976 he led the scientific edition of Atlas - thematic city maps (Warsaw 1976) which was intended by the Head Office of Geodesy and Cartography to become a model for large scale thematic maps connected to inventory and spatial planning. In the second half of the 1970s work on Atlas of Legnickie Voivodship was started under his supervision. Until 1983 a complete set of 105 maps on 45 plates was prepared. This innovative work was never published because of the withdrawal of the Project Office of KGHM "Cuprum" from cooperation. This ruined several year efforts of the Professor and his team.
In 1985, undaunted by the failure of the previous project, W. Pawlak took up the initiative of Prof. Alfred Jahn to prepare a regional atlas of Silesia in cooperation with the Wrocław unit of the Polish Academy of Sciences. The publication was intended to celebrate the 50th anniversary of the foundation of a Polish university in Wrocław. Nominated by the rector of Wroclaw University to the position of the editor in chief, he organized the Laboratory of the Atlas of Lower Silesia, of which he became the head. As the scientific editor and author of the atlas concept and dummy, he selected the authors, decided on map contents with them as well as prepared some maps himself.

Over ten years of labor resulted in Atlas of Lower and Opole Silesia (Wrocław 1997), which included about 500 maps, with titles and legends translated into English and German. This work evades any simple classification. Formally it is a regional atlas, but because of its range of contents and comprehensive approach to the knowledge about the region it is actually closer to national atlases. Undoubtedly, it is one of the best regional atlases in the world. The efforts of Prof. W. Pawlak and his team were recognized in the form of awards granted by the minister of Internal Affairs and Administration (1998) and minister of National Education (1998).

After having completed his work on the atlas, Professor accepted the role of a consultant and reviewer of cartographic and IT standards in large scale thematic maps of Poland. He participated in the elaboration of the amendment to the technical guidelines for Sozological map of Poland 1:50 000 (1997, 2004) and Hydrographical map of Poland 1:50 000 (1997, 2004). He was also a co-author of commentaries to several dozen sheets of these maps published in 1997-2001.

After his retirement on 31st December 2001 he continued his scientific and didactic work in collaboration with the Department of Cartography of Wrocław University. Until 2007 he headed the Laboratory of Atlas of Lower Silesia, where together with his team he prepared the second, updated and extended edition of Atlas of Lower and Opole Silesia (Wrocław 2008). He also edited and published Geographic Atlas of the World (2001), which was an adaptation of the German school atlas of Westermann. In the meantime he also published several important review articles devoted to the father of Polish cartography, Eugeniusz Romer: Genesis of 
Romerian cartography ("Polish Cartographical Review" 1995), Influence of Romerian school on the Polish Cartographical Publishing House ("Polish Cartographical Review" 2001), Eugeniusz Romer as a geographer and cartographer ("Studies and Materials from the History of Cartography" 2004), Contribution of Eugeniusz Romer and his school into the development of Polish cartography ("Library of Polish Cartographical Review" 2008).

During his academic career Professor Pawlak promoted more than $\mathbf{2 0 0}$ graduates of cartographic specialty and eight doctors, three of which: Wiesława Żyszkowska, Beata Medynska-Gulij and Andrzej Konias later received habilitation degrees.

Beside scientific and didactic activity, Professor Pawlak also participated in organizational actions of Wrockaw University and other scientific institutions as well as professional associations of cartographers and surveyors. In 1978-1981 he held the post of the director of the Geographical Institute of Wrocław University. In 1980 he became the head of the Department of Cartography, the post he kept until the end of his professional career in the Geographical Institute on 31st December 2001. In 1987-1990 and 1993-2001 he was a Deputy Dean at the Department of Natural Studies of Wrocław University.

From 1971 he was a member of the Polish Geographical Society, where he held the post of the head of the Cartographic Commission (1981-1987), later to become the vice-president of the Cartographic Division of Polish Geographical Society. In 2000-2003 he was a member of the Board of Polish Geographical Society. $\mathrm{He}$ also headed the Editorial Committee of quarterly "Polish Cartographical Review" published by Polish Geographical Society (1998-2011). He was a member of the Committee of Geographical Sciences at the Polish Academy of Sciences. He was also an arbiter in the Copyright Unit at the Ministry of Culture and Art (1998). For many years he had been a member of the Committee for General Cartography at the President of the Head Office for Geodesy and Cartography and a member of the Certificate Commission for professional certification in geodesy and cartography (1997).

In 1985 W. Pawlak initiated cartographic schools - national conferences of scientific-educational character. Until 1995 Wrocław University under his leadership organized five out of nine schools. After a five year break, in 2000 he returned to the idea and reactivated the schools under the title "Main problems of contemporary cartography" (2000-2011). As the main originator and organizer, Professor Pawlak actively participated in the schools until 2007. He edited or co-edited the first volumes of the monography "Main Problems of Contemporary Cartography" (2000, 2001, 2002; together with Waldemar Spallek 2004, 2005, 2006), which comprised the aftermath of the schools. Currently Wrocław cartographic schools, in the form of international conferences in English are held biannually.

For his merit in the field of science and education Professor Władysław Pawlak was awarded the Golden Cross of Merit and the Knights Cross of the Order of Polonia Restituta. He also received the Medal of Polish Geographical Society and the Professor Makowski's Medal of the Association of Polish Cartographers for contribution input into the development of Polish cartography.

In the person of Professor Władysław Pawlak the academic community of Wrockaw University and Polish cartography lost an outstanding scientist, teacher and educator. We will remember his expressive views on cartography which provided rejuvenating impulses during discussions at numerous conferences and other scientific meetings. We will also remember him as a titan of work, who persevered to reach his goal which was a comprehensive and complete elaboration of articles, maps and atlases. While at it, he never forgot about the graphic and editorial aspect of maps. During his classes with students he conveyed his theoretical and practical knowledge in the area of edition of maps and atlases.

The funeral of Professor Władysław Pawlak took place on 8th August 2016 at the Osobowicki Cemetery in Wrocław. A month later, on 16th September 2016, Professor's collaborators and students organized a commemorative academic farewell of the honored Departed. During the meeting representatives of the University and other institutions delivered speeches, presented Professor's biography and eulogies. In the autumn of 2017, during the 40 National Cartographic Conference in Wrocław, a special scientific session devoted to the person and heritage of Professor Władysław Pawlak will be organized.

Waldemar Spallek (Wrocław) 